\section{SCIENCE AND THE REAL FREEDOMS}

$\mathrm{T}$

$\mathrm{HE}$ critical economic situation in which Britain finds herself requires all possible scientific help. The contribution of men of science can be as vital to our national recovery as any gains won by the miners in the battle for coal. But this depends on whether men of science are in a position to act, and whether their efforts are properly organised and integrated on a national scale.

The speakers at a recent conference on "Science and the Real Freedoms" convened by the Association of Scientific Workers dealt with these issues so far as they affect the freedom of men of science to develop their knowledge and the opportunity to see it applied to the main economic problems of the country. In opening the meeting, Sir Robert WatsonWatt pointed to the substantial progress that has been made towards the planning of scientific effort. Members of the Association particularly welcome the formation of the committees for military and civil science under the chairmanship of Sir Henry Tizard. Also encouraging are the scientific organisation within the National Coal Board and the provisions of the Industrial Organisation Bill. But still there remain severe limitations on the development and use of science, which we would be unwise to ignore.

The scale and nature of the effort applied to the development of new weapons of war, which offer us the possibility of mass destruction of quite unprecedented extent, is a source of disquiet. The man of seience, as a key man in this development, works behind the screen of military security, cut off from free intercourse with other scientific workers by dangerously ill-defined and ill-conceived secrecy restrictions. The Official Secrets Act, which someone once quite seriously described as "the Act to repeal Magna Carta", is singularly unclear in the burdens, often of retrospective responsibility, which it puts on State servants and ordinary citizens alike. Safeguards are essential, but they should be specific, clear, comprehensible and limited. At present it seems that timid minds are imposing a stricter and more extensive secrecy than is necessary, with the result that our own scientific progress is perhaps hampered as much as that of a potential enemy.

Restrictions, Sir Robert said, are not confined to the military field. It is the habit of industrialists to accuse the bureaucrat of an exclusive taste for restrictions. However, they themselves must take some of the blame for certain economic shortcomings. For a long time sections of industry have imposed limitations on the development and interchange of new ideas and techniques, occupied research workers on circumventing the patents of others, and used blacking patents of their own to ward off the necessity of making new capital investments.

Talk on 'freedoms' has been too much directed to the passive freedoms, 'freedoms from'; and too little to the active freedoms, 'freedoms for' and 'freedoms to'. While men of science have been accustomed to claim for themselves the right to choose, to learn, to read, speak, think and write as they will, they have not put enough effort into the harder task of winning the freedom to investigate, to study scientifically within the industries themselves and by their own methods the problems which they consider important to the life of the community.
The scientific worker in industry is seldom given the chance to investigate adequately the problems of production and development in his section of industry, nor is he in a position to undertake the full application of war-time discoveries to production techniques. There is clearly an urgent need of extension of freedom to penetrate in this direction.

Sir Robert Watson-Watt ended with a word of caution. It should be remembered that the outcome of any project of scientific research is unforecastable. As men of science we cannot say explicitly at the outset what may be expected from the investigations which we feel we must be free to undertake. The user does not know what to ask for ; the investigator does not know what he can promise. But as to the great advantages which will arise from the organised application of research and scientific method, we have no doubts and many proofs. The opportunity which men of seience now have of proving the value of their methods in overcoming our economic diffi. culties must not be lost.

Dr. E. H. S. Burhop, former member of the British team of atomic scientists in America, spoke of the loss of what might be called the natural rights of men of science. Such men have advanced funda. mental knowledge in the past, because there have been free exchange of information and collaboration across frontiers and between workers in the different branches of science. Now secrecy has split them in camps, and the ominous delay in ending it is a symptom of the preparation of another world war. In view of the great dangers involved, the Association of Scientific Workers feels that it is time for men of science to decide what they can do collectively and individually to better this situation.

To one who has come to recognize a traditional fairness in British justice, some of the provisions of the Official Secrets Act are alarming. Under it the normal rights of citizens to a fair trial are superseded, and the onus of proof of innocence is placed on the accused. It is not necessary, Dr. Burhop said, for the prosecution even to prove that any specific offence has been committed; only that the character of the accused makes it appear probable that he has com. mitted such an offence. Moreover, many people are under the misconception that this Act applies only to those in Government service. In fact it applies to everyone in the country.

We have, as a warning of what might happen, the hysteria and false accusations which followed the revelations of a spy-ring in Canada. There is also the case of Dr. Nunn May, which arose similarly out of the secrecy Britain and the United States have imposed on the atom bomb. While the Association does not condone his offence, to which he himself had pleaded guilty, it did feel justified in asking for a marked reduction in his ten-year sentence. If the harshness of this was intended as a deterrent on other men of science, it was a success in so far as it made many have second thoughts about taking any part at all in the development of atomic energy in Britain.

Dr. Burhop recalled the circumstances of the ban placed on certain British and American scientific workers from travelling to Moscow, when the war with Germany had ended, and the Japanese war was in its last stages. He doubts if any atomic physicist would even now have the temerity to apply for permission to travel to the U.S.S.R. or Eastern Europe. As new techniques of mass destruction are developed, the ban might involve other scientific workers besides the atomic physicists. 
The Association advocates the complete publication of all results of scientific research, which has been suppressed for reasons of military security, as soon as the Security Council is operating a plan which outlaws the use of weapons of mass destruction, and which provides for a general reduction and control of armaments. Even while the present situation continues, secrecy should be confined to certain technical aspects of weapon development. As a means of re-establishing wide international relations, continued support for U.N.E.S.C.O. and for the recently formed World Federation of Scientific Workers is essential. Moreover, men of science, including those working on atomic energy, should be allowed and encouraged to visit workers in other countries.

We have to be vigilant concerning national restrictions on the freedom of men of science. Under the Atomic Energy Act scientific workers have no welldefined rights of access to scientific information connected in any way with atomic energy. Decisions on these matters depend on the Minister of Supply and his official advisers, and the effects of these decisions will have to be carefully watched. Wherever they work, men of science should have a legal right to the publication of their results. All should be employed on the basis of service contracts, in which are clearly defined their rights and duties in their particular job.

Prof. J. D. Bernal opened his address with the words: "The real freedoms of science not only include freedom from crippling restriction, but freedom to give of one's best in the service of the community. Such freedom is more than individual freedom. It is a collective freedom implying organisation of scientists by scientists in relation to all aspects of national activity."

There is nothing essentially new in the serious economic situation which confronts us to-day. As a culmination of our failure to organise and use our scientific resources efficiently, it has proved conclusively our worst fears and forecasts. Only men of science can see where and for what purposes they themselves are needed. It will be on their own initiative that they will take part in the national recovery.

The White Paper on the economic situation is no more than an able diagnosis of the trouble. When it comes to the cure, all it offers are pious hopes. Unless there is energetic planning, even the necessary minimum of a 40 per cent increase in exports will not be realized. On top of this the international situation looks as though it might get worse in the coming year.

In maintaining our present foreign policy we are keeping $1 \frac{1}{2}$ million of our twenty million workers in the Armed Forces. About half a million more are engaged on the production of military supplies. The wastage is relatively greater when one considers our scientific man-power. At the present time about one half of the governmental scientific expenditure is allocated to military research, and clearly the ending of war preparations would release a larger proportion of scientific workers for productive work.

The essential and most urgent need is to consider the best way of organising scientific effort for helping to solve the short- and long-term problems facing us in the industrial sphere in Great Britain. We need a similar organisation and status to that of the operational research teams during the War. This is essential both in those Ministries responsible for our industries, and within the national development councils envisaged under the Industrial Organisation Act. In addition, men of science are needed at Cabinet office level working in co-operation with the Joint Planning Staff. The existence of the Tizard Committees provides the nucleus for such a scientific general staff.

In all this, it is clear that men of science can only analyse the situation and advise on the best policies to pursue. They can provide knowledge on which wise action could be based, but not the action itself. It is up to the Government to take adequate powers to ensure the implementation of the policies decided upon.

About the responsibilities of men of science, Prof. Bernal urged that they take active steps to ensure the widest possible knowledge of the technical situation of the country. The Tizard Committees cannot become fully effective in a normal Civil Service atmosphere, unless there is a possibility of mobilizing public opinion for research and against obstruction. It needs sustained activity on the part of scientific workers to see the necessary plans through to successful completion.

In the discussion, two delegates from the Amalgamated Engineering Union spoke of the attitude of the factory workers to scientific developments. The workers do not take kindly to innovations when, as in one factory, output was trebled but wages scarcely raised. Nor can they easily understand the attitude of the man of science, when he speaks of the importance of freely sharing his knowledge. In the artisan class, particularly, there is a tendency not to pass on information, since in times of unemployment only the most skilled and valuable men keep their jobs. It is necessary for the men of science to explain their methods and to prove their value to the working people. In that way they would win the willing co-operation of the trade union movement.

\section{HEREDITARY (SEED-BORNE) SYMBIOSIS IN CASUARINA EQUISETIFOLIA FORST.}

\author{
By Prof. S. R. BOSE \\ Carmichael Medical College, Calcutta
}

$\mathrm{E}$ VERY Casuarina equisetifolia plant examined has been found to have mycelia of Phomopsis casuarince F. Tassi extending throughout into every organ, beginning from the seed-coat. Cutting a section of the seed-coat of Casuarina and staining in picro-nigrosin or cotton blue one can see finely branched and septate hyphæ within the tegmen (see accompanying illustration). Only the resting embryo with two cotyledons is free from fungal infection. In samples of tomato and apple seeds from some apparently healthy fruits from Calcutta markets, I have seen a network of copiously branched and septate hyphæ in the tegmen under the microscope. Dennis ${ }^{1}$ recently remarked that "fungi capable under favour. able circumstances of parasitizing economic plants such as potato, tomato and apple may be found in nature as saprophytes on herbaceous weeds". I wonder whether Dennis had examined microscopically sections of clean seeds of the various economic plants to locate any possible Phoma hyphæ within the tegmen before planting them in the virgin soil. Oxley and Jones ${ }^{2}$ found, under the epidermis of 